\title{
Study on Legal Responsibilities of Kindergarten Accidents
}

\author{
Mei Liu \\ Kunming University \\ Kunming, China
}

\author{
Rong Li \\ Kunming University \\ Kunming, China
}

\begin{abstract}
In recent years, kindergarten accident began to attract public attention due to its high frequency and great social impact. In these cases, opinions vary on in which case kindergartens shall be responsible and what responsibilities should kindergartens shoulder. However, existing Chinese laws and regulations are too simple and unsystematic. To fully know about related issues and solutions regarding kindergarten accident, the author utilizes legal principles to expound on them in terms of concept, types of accidents, the principle of imputation, requisites for liability and other aspects, with the hope to contribute to legal construction and theoretical study of kindergarten accident.
\end{abstract}

\section{Keywords—kindergarten; accident; legal responsibility}

\section{INTRODUCTION}

Injury accidents of infants in kindergartens take place from time to time, in such circumstances, no matter whether kindergarten is accountable for that, kindergarten used to patch up a quarrel and reconcile the parties concerned by means of settlement in private such as compensation to solve the problems, but both kindergarten and parents feel wronged. As people know more about law, children's guardians and kindergarten are all eager to address children injury accident on campus fairly and justly through legal ways. Although the Ministry of Education implemented Measures of Handling Student Injury as early as September 1, 2002, but students, parents, society and even schools still have many vague opinions on the responsibilities that school shall assume when personal injury accident occurs on campus. Therefore, strict definition of the scope of responsibility of kindergarten accident and further clarification of the principle of imputation of such accidents not only make for the scientific settlement and effective prevention of personal injury to kindergarten children, and also can provide a reference for legislation on preschool education with important theoretical and realistic significance.

\section{TYPES OF KINDERGARTEN ACCIDENTS}

Kindergarten accident refers to personal injury accident of children while at kindergarten. The scope and types of accidents are very complex. Generally they can be categorized into the following types.

- Substandard facilities lead to scratch, fall or death of

This is the final achievement of the "Investigation and Legal Study on Educational Punishments by Schools" for the 2015 Project of Scientific Planning Of Philosophical Social Science Education of Yunnan (Project No.: AC15012). children. Teaching building, walls, doors, windows, stairs, handrails, and outdoor large toys (children's slide, ladders, swing, etc.) of kindergarten have potential safety hazards for worn down by the years without repair, and kindergarten does not repair or replace them in a timely manner, which lead to children injury or death.

- Dereliction of teacher and childcare staff causes harm to body and mind of children. Mental or bodily harms caused to children by negligence of duty of teacher and childcare staff at work mainly are behavioral faults of teacher or childcare staff in the process of children care (for example, corporal or mental punishment imposed on children), which cause physical or/and mental harm to children. Children health is affected because of negligence of medical staff. Negligence of medical staff mainly includes: using wrong vaccine, taking wrong medicine; problems existing in meals and sanitary condition of kindergarten canteen cause harms to students, such as diarrhea and poisoning. Besides, lack of emergency measures in response to emergencies.

- Children is abducted because of lax security system. Many doorkeepers of kindergartens and children pickup system primarily use forms such as notice and bulletin and lack systematic written rules and regulations. Both parents and kindergartens do not raise strict requirements for picking up children, parents pick up children at will, some ask others to pick up instead, some pick up ahead of time, some pick up children without letting the teacher know. These loopholes in management give an opportunity to lawbreakers, who take advantage of infant ignorance, taking children away by pretending to their relative or lying that their parents have an accident and so on.

- Sudden injury accident caused by children themselves, mainly including infant congenital diseases, such as epilepsy, congenital osteogenesis imperfecta and congenital anhidrosis; lesion occurs in some organs of children, accidents happen of which parents and teachers are not aware; parents purchase things like clothes or school supplies that have potential safety hazards for their children. 
- Children hurt each other when playing or quarreling, personal injury caused by a third party rather than kindergarten to children. The personal injury caused by force majeure, etc.

\section{LEGAL RELATION BETWEEN KINDERGARTEN AND CHILDREN}

Educational legal relationship is the interpersonal relationship of rights and obligations formed in the process of adjusting educational activities on the part of educational laws and norms [1]. Educational legal relationship mainly consists of the following aspects: the relationship between divided powers of governments at all levels in terms of educational administration, the relationship between schools and educational administrative department, the relationship between schools and faculty, and the relationship between schools and students. Among them, the relationship between schools and students is an important part of educational legal relationship. The educational legal relationship is exceedingly complicated, but can be summarized into two relationships - educational administrative legal relationship and educational civil legal relationship.

\section{A. Educational Administrative Legal Relationship between Kindergarten and Children Generated by Educational Management}

Receiving education is a fundamental right and duty endowed to citizens by the Construction of China. The Article 46 of The Constitution of the People's Republic of China stipulates that "citizens of the People's Republic of China have the duty as well as the right to receive education". Corresponding to the right and the duty of the citizens to receive education, the country exercises the right of education, hence, right of education is closely linked to national public power. But in actual practice, the performers of national public power not only include statutory educational administrative departments, for citizens, Chinese public schools are not state organs though but act as an exerciser of public power in fact and form a special educational administrative relationship with students. In this relationship, schools exercise the rights of education and management in the capacity of administrative subject, including enrollment right, power of educational management, power of student status management, power of administrative sanction, power of administrative reward and power of issuing academic certificates, and meanwhile shoulder the obligation and duty to educate students. So to speak, educational administrative legal relationship is a quasi-administrative legal relationship.

\section{B. Educational Civil Legal Relationship between Kindergarten and Children Generated by Educational Protection}

Civil legal relationship is a type of legal relations, and it is a civil relationship containing civil rights and obligations between concrete civil subjects in accordance with requirements of legal right mode stipulated by civil law. Civil legal relationship is a result of civil law's adjusting property relationship and personal relationship between equal subjects and is a combination of property relationship and personal relationship between equal subjects and form of civil law, and is a civil relationship in nature, which is under mandatory protection of civil law [2]. According to the Article 39 of the Education Law of the People's Republic of China, Schools and other educational institutions who have satisfied conditions for legal persons shall obtain the status of legal persons from the date of approval or registration of legal persons. That is to say, schools shall obtain the status of legal persons and shall enjoy civil rights and bear civil liabilities according to law from the date of legal establishment. When a school engages in civil activities in the capacity of a civil subject and enjoys civil rights and bears civil liabilities, its legal relationship with students is civil legal relationship. The contents of civil legal relationship between schools and students are civil rights and civil liabilities that shall be enjoyed and born by schools and students. Objects of civil legal relationship between schools and students include object, intellectual property, behavior, and personal interest. At present, the legal disputes between schools and students are mainly caused by student's personal interest infringed by school. They are mainly embodied in injury incidents of students.

To sum up, there can be two different legal relations between schools and students under different circumstances. These two legal relations are different in both nature and content, so they are not interchangeable. The determination of quasi-administrative legal relationship is very necessary for the advocacy of a unified leadership and management of school. Furthermore, determination of civil legal relationship is essential to endow students with independent qualifications of civil subject and ensure full realization of all rights of students.

\section{PRINCIPLE OF IMPUTATION FOR KINDERGARTEN ACCIDENT}

\section{A. Kindergarten Accident Applies to the Principle of Fault Liability}

Fault liability is the liability which shall be borne by the doer for at fault subjectively and thus causing damage to others [3]. According to whether requisites for liability take fault of parties concerned as a key element, we categorize liability into fault liability, no-fault liability and fair liability. The General Principles of The Civil Law of China explicitly stipulates that "Civil liability shall still be borne even in the absence of fault, if the law so stipulates." We can know from this that assuming no-fault liability must be premised on explicit stipulations of law, but now there is no laws and regulations in China that stipulate that responsibility of school accident applies to the principle of no-fault liability. Therefore, when determining whether kindergarten shall assume responsibilities, at first we should see whether kindergarten or teacher is at fault subjectively, if they are, they shall assume responsibilities, if they are not, they shall bear no responsibility. Here "subjective fault" refers to subjective mental attitude of the doer, including intent and negligence. 


\section{B. Kindergarten Accident Applies to the Principle of Presumption of Fault}

Presumption of fault is also known as presumption of negligence. In tort law, when victim is at law, on the condition that causal relationship between unlawful behavior and fact of damage can be proved, if injurer is unable to prove he or she is not at fault for the occurrence of the damage, then it is presumed that the defendant is at fault in the damaging behavior according to fact of damage and shall bear the liability for compensation. The principle of presumption of fault is the principle of imputation which presumes that injurer is at fault according to fact of damage rather than proof of victim and thus determines liability for tort of injurer. The Article 40 of Tort Liability Law stipulates that "if personal injury is inflicted on a person with no or limited capacity for civil conduct during the course of studying or living in a kindergarten, school or other institutions of learning by persons other than personnel of the kindergarten, school or institution of learning, the kindergarten, school or institution of learning shall be liable for supplementary liability if it has failed to fulfill its management responsibilities." The principle of presumption of fault is the principle of imputation which presumes that doer is at fault according to fact of damage in a special tort and thus determining that doer at fault shall bear the liability for compensation. In our tort law's principle of imputation system, the principle of fault liability applies to the imputation of general torts, the principle of assumption of fault applies to the imputation of various special torts. Tortious accident in school is often caused by general civil torts and generally applies to principle of fault imputation, but does not exclude the situation where school has a special tort. Minors under ten who suffer from injury in kindergarten or school often find it hard to offer proof for unlawful act and causality for they are limited by age, therefore, generally the principle of presumption of fault is applied to determination of faults. In other words, when kindergarten or school causes harm to persons without capacity of civil conduct because they cannot perform necessary duty of care, they shall assume civil responsibilities. School shall assume presumed responsibility for fault in the following three types of student injury accidents:

- Student injury accidents caused by school construction;

- School buildings or other facilities or objects and hangings put on buildings collapse, fall off or drop, resulting in student injury accident;

- Student injury accident caused by school's violation of security obligation [4].

\section{RESPONSIBILITY ASSUMED BY KINDERGARTEN IN KINDERGARTEN ACCIDENT}

\section{A. Bear All Legal Responsibilities}

First, if fault or negligence on the part of kindergarten or teacher at work directly causes children injury accident, kindergarten or teacher shall assume legal responsibilities. Second, if children injury is caused by individual behavior of staff in kindergarten or teachers that has nothing to do with their duties, or intended act performed by children, teachers or other individuals, legal responsibilities shall be borne by the doer.

\section{B. Bear Partial Legal Responsibilities}

First, if kindergarten and teacher are at fault at work, such fault becomes one condition for the occurrence of the accident but does not constitute its immediate cause, then kindergarten or teachers should assume partial responsibilities. Second, kindergarten or teacher bear education and management responsibilities for under-age students according to law, if children himself or herself is harmed or harm is caused to other children because of improper children management, kindergarten or teacher shall bear certain civil legal responsibilities.

\section{Bear No Legal Responsibility}

Kindergarten is not responsible for children in the following circumstances:

- It happens when children is on the way to school or home by himself or herself;

- Children has an outbreak of illness, kindergarten takes rescue measures in time;

- Child injures himself or herself in school activities, and kindergarten manages properly;

- The accident is caused by children himself or herself or between children, and kindergarten manages properly;

- It is caused by a third party instead of kindergarten and children, and kindergarten manages properly;

- It is caused by personal behavior of faculty outside the campus, which has nothing to do with their duties; 6 . It is caused by force majeure.

As for children injury that happens outside the kindergarten but takes place in activities organized by kindergarten, we need to determine whether kindergarten is at fault and the gravity of fault, if the school is at fault indeed, then it shall assume relevant legal responsibilities, the school shall bear partial legal responsibilities if at partly fault, or undertake all legal responsibilities if fully responsible for the fault.

\section{CONCLUSION}

In terms of kindergarten, although kindergarten is faultless and does not need to assume any legal responsibility, but humanitarianly speaking, kindergarten may offer economic aid to injured children or set up a relevant compensation fund for solution. Paragraph 2 of the Article 26 of the Measures of Handling Student Injury states the similar viewpoint, stipulating: "If not responsible, school may offer proper help to injured student in the principle of voluntariness and possibility according to actual circumstance, if possible." In addition, we may encourage kindergarten to take out liability insurance and encourage 
children to take out personal injury insurance. This is the most feasible and effective way to solve kindergarten accident, as well as the method adopted by many countries. Actual situation shows that kindergarten liability insurances and children personal accident insurances set up by some insurance companies with kindergarten as beneficiary can effectively solve risks issues in school education and teaching.

\section{REFERENCE}

[1] Zheng Liangxin. General Educational Law [M]. Nanning: Guangxi Education Express, 2000:36.

[2] Jiang Pingzhu. Science of Civil Law [M]. Beijing: China University of Political Science and Law Press, 2000:73.

[3] Wei Zhenying. Civil Law [M]. Beijing: Peking University Press, 2000.43.

[4] Tao Yunfeng \& Liu Wei. Outline of Imputation Principle of Student Injury Accident at School-Diversified Imputation Liability System Design [J]. Journal of Adult Education of Gansu Political Science and Law Institute, 2007, (6). 